\title{
Persepsi Guru Serta Siswa Terhadap Penggunaan Google Classroom dalam Pembelajaran Daring Sosiologi Kelas X IPS SMA Negeri 9 Mandau Duri
}

\author{
Zulfaa Nabiila Zufni ${ }^{1}$, Junaidi Junaidi ${ }^{2}$ \\ ${ }^{1,2}$ Universitas Negeri Padang \\ Email: zulfaanabiila28@gmail.com, junaidi@fis.unp.ac.id
}

\begin{abstract}
Abstrak
Penelitian ini bertujuan untuk mendeskripsikan persepsi guru serta siswa terhadap penggunaan google classroom dalam pembelajaran daring sosiologi kelas X IPS di SMA Negeri 9 Mandau. Hasil penelitian ini berguna bagi sekolah dan guru sebagai evaluasi dalam mengatasi pembelajaran di era pandemi dan untuk meningkatkan inovasi dan kreativitas dalam pembelajaran selanjutnya. Penelitian ini menggunakan pendekatan kualitatif dengan tipe studi kasus. Teknik pemilihan informan yang dipilih adalah purposive sampling. Teknik pengumpulan data dilakukan dengan cara observasi, wawancara, dan studi dokumentasi. Data dianalisis menggunakan teknik dari Miles dan Huberman terdiri atas reduksi data, penyajian data, dan penarikan kesimpulan. Penelitian ini dianalisis dengan Teori Konstruktivistik dari Jean Piaget. Hasil penelitian menunjukkan bahwa persepsi guru dan siswa dalam menggunakan google classroom dinilai mudah digunakan dan tidak membutuhkan waktu yang lama dalam melakukan kegiatan pembelajaran. google classroom juga bisa digunakan untuk melakukan penilaian seperti ulangan harian, membelajarkan sikap serta keterampilan dan juga terlihat adanya konteks interaksi antara guru dan siswa selama proses pembelajaran.
\end{abstract}

\section{Kata kunci: Google Classroom, Persepsi, Pembelajaran Sosiologi}

\section{Abstract}

This study aims to describe the perceptions of teachers and students about the use of google classrooms in online learning sociology class X IPS at SMA Negeri 9 Mandau. The results of this study are useful for schools and teachers as an evaluation in overcoming learning in the pandemic era and for increasing innovation and creativity in subsequent learning. This research uses a qualitative approach with a case study type. The technique for selecting the selected informants was purposive sampling. The data collection technique was done by means of observation, interview, and documentation study. Data were analyzed using techniques from Miles and Huberman consisting of data reduction, data presentation, and drawing conclusions. This research was analyzed using the Constructivistic Theory by Jean Piaget. The results showed that the perceptions of teachers and students in using google classroom were considered easy to use and did not require a long time to carry out learning activities. Google classroom can also be used to conduct assessments such as daily tests, teach attitudes and skills and also shows the context of interaction between teachers and students during the learning process.

Keywords: Google Classroom, Perception, Sociology Learning

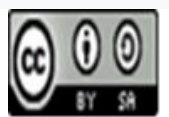




\section{Pendahuluan}

Belajar adalah suatu proses pengembangan pengetahuan, keterampilan, dan sikap dalam ranah baru yang terjadi ketika seseorang berinteraksi dengan lingkungan. Proses belajar dapat berlangsung karena adanya suatu interaksi yang dilakukan antara guru dan siswa yang disebut dengan pembelajaran. Pembelajaran adalah proses untuk membantu peserta didik agar dapat belajar dengan baik (Sari, 2015).

Pada awal tahun 2020 tepatnya awal bulan Februari kita dihadapkan dengan adanya wabah yang mengganggu warga masyarakat termasuk siswa yang dinamakan dengan Corona Virus Disease atau yang lebih dikenal dengan sebutan corona atau covid-19. Wabah ini memiliki dampak yang membahayakan untuk seluruh dunia, sehingga banyak sekolah, kantor, instansi pemerintahan yang tutup selama pandemi ini. Adanya pandemi covid 19 pada awal tahun 2020 ini berdampak pada seluruh bidang yang ada, tak terkecuali di bidang pendidikan. Semua kegiatan pembelajaran konvensional mulai diliburkan sementara waktu. Sistem pembelajaran konvensional yang dilaksanakan oleh sebagian guru perlahan beradaptasi dengan berbagai aplikasi pembelajaran daring yang dapat memberi ruang interaksi langsung antara guru dengan siswa tanpa harus bertemu secara tatap muka.

Guru adalah semua orang yang berwenang dan bertanggung jawab terhadap pendidikan murid-murid, baik secara individual maupun secara klasikal, baik di sekolah maupun di luar sekolah. Selain itu, guru juga merupakan semua orang yang berwenang dan bertanggungjawab untuk membimbing dan membina anak didik, baik secara individual maupun klasikal, di sekolah maupun di luar sekolah. Guru adalah orang yang bekerja dalam bidang pendidikan dan pengajaran yang ikut bertanggung jawab dalam membantu anak-anak mencapai kedewasaan masing-masing (Uno \& Lamatenggo, 2016). Guru bukanlah sekedar orang yang berdiri di depan kelas untuk menyampaikan materi pengetahuan tertentu, melainkan anggota masyarakat yang harus ikut aktif dan berjiwa bebas serta kreatif dalam mengarahkan perkembangan anak didiknya untuk menjadi anggota masyarakat sebagai orang dewasa. Sedangkan siswa adalah mereka yang secara khusus diserahkan oleh orang tua untuk mengikuti pembelajaran yang diselenggarakan di sekolah dengan tujuan untuk menjadi manusia yang memiliki pengetahuan, keterampilan, berpengalaman, berkepribadian, berakhlak dan mandiri (Ali, 2010). Siswa memiliki pribadi yang unik yang mempunyai potensi dan mengalami perkembangan (Darajat dalam Bahri, 2011). Pada era distrupsi sekarang ini, guru dan siswa bahkan orang tua dipaksa beradaptasi secara cepat dengan metode ini. Memang di tengah situasi ini pembelajaran daring dirasa solusi yang paling tepat untuk dilakukan.

Pembelajaran dalam jaringan (daring) yaitu proses pembelajaran yang memanfaatkan jaringan internet sehingga kegiatan yang bisa dilakukan dari rumah dan bisa dilakukan kapan saja sehingga tidak menjadikan masalah karena pembelajrannya tidak terikat oleh waktu (Eka, 2018). Tujuan pembelajaran daring ialah memberikan layanan pembelajaran bermutu dalam jaringan yang bersifat masif dan terbuka untuk menjangkau peminat ruang belajar agar lebih banyak dan lebih luas (Sofyana \& Rozaq, 2019). Pembelajaran daring merupakan bentuk penyampaian pembelajaran konvensional yang dituangkan pada format digital melalui internet (Annisa, 2019).

Ada beberapa masalah yang terjadi pada saat pembelajaran daring seperti masih kurangnya kompetensi guru dalam menerapkan pembelajaran daring. Sebagian guru memanfaatkan media elektronik tersebut untuk mempermudah guru dalam pembelajaran. Guru hanya memberikan materi dan tugas namun masih kurang dalam menjelaskan materi, sehingga banyak siswa yang mengeluh tertinggal materi pembelajarannya, dan kesulitan dalam memahami soal-soal yang telah diberikan oleh guru yang membuat siswa merasa tidak tertarik dengan materi pembelajaran yang disampaikan oleh guru. Biasanya guru hanya melakukan suatu pembelajaran yang monoton sehingga siswa mengalami kejenuhan dalam belajar. Kejenuhan belajar terjadi akibat dari adanya tuntutan bagi peserta didik untuk selalu mematuhi

Jurnal Sikola: Jurnal Kajian Pendidikan dan Pembelajaran Vol. 2, No. 4, Th. 2021 
aturan tugas-tugas yang diembankan untuk siswa. Kejenuhan belajar juga terjadi karena kegiatan yang selalu sama yang dikerjakan oleh siswa disetiap harinya. Kejenuhan belajar ini akan sangat berdampak bagi siswa untuk keberlangsungan pendidikannya. Kemudian fokus siswa yang berkurang karena tidak melakukan tatap muka secara langsung. Siswa menginginkan inovasi pembelajaran baru yang bisa meningkatkan minat belajar.

Selain itu pada pembelajaran daring juga sangat singkat sehingga keutuhan kegiatan pembelajaran yang terdiri dari kegiatan pembuka, isi dan penutup menjadi terabaikan sehingga kegiatan penutup terutama untuk mereview pembelajaran menjadi berkurang. Misalnya dalam pembelajaran tatap muka untuk kelas $X$ jumlah pertemuan tiap minggu ada $2 \mathrm{x}$ pertemuan dengan durasi 2 jam 1 kali pertemuan, 1 jam nya dihitung 45 menit. Sedangkan pada pembelajaran daring jumlah pertemuan perminggu hanya 1 kali dan jumlah jamnya juga berkurang menjadi 30 menit.

Salah satu aplikasi yang digunakan dalam pembelajaran daring adalah perangkat yang dikembangkan oleh google yaitu google classroom. Google classroom merupakan suatu pemanfaatan teknologi internet dalam pengelolaan pembelajaran dengan jangkauan yang luas. Google classroom adalah platform pembelajaran campuran yang dikembangkan oleh google untuk sekolah atau institusi pendidikan lainnya yang bertujuan untuk menyederhanakan pembuatan, pendistribusian, dan penerapan tugas dengan cara tanpa kertas (Imaduddin, 2018). Melalui google classroom ini para pengajar dapat mengelola materi pembelajaran, misalnya mengunggah materi, memberikan tugas kepada siswa, menerima pekerjaan membuat tes/ kuis, memberikan nilai, memonitoring keaktifan, mengelola nilai, berinteraksi dengan peserta didik dan sesama tim pengajar, melalui forum diskusi atau chat, dan lain-lainnya. Sebaliknya siswa dapat memanfaatkan dengan mengakses tugas, materi pembelajaran, diskusi dengan siswa lainnya dan guru, melihat percakapan dan hasil belajar.

Salah satu sekolah yang memanfaatkan teknologi informasi dan komunikasi dengan aplikasi google classroom adalah SMA Negeri 9 Mandau. Salah satunya dalam pembelajaran sosiologi. Pembelajaran sosiologi sangat penting untuk dikembangkan karena, sosiologi selalu ada dalam kehidupan sehari-hari. Sosiologi atau ilmu masyarakat ialah ilmu yang mempelajari struktur sosial dan proses-proses sosial, termasuk perubahan-perubahan sosial (Soekanto, 2012). Sosiologi adalah ilmu yang mempelajari hubungan antara manusia satu dan lainnya di dalam suatu kelompok berakibat timbulnya pola hubungan antar manusia guna menghindari benturan antar-individu, dan individu dengan kelompok. Secara singkat sosiologi ilmu yang berobjek pada pola-pola hubungan antar manusia (Setiadi \& Kolip, 2011).

Memasuki semester genap tahun ajaran baru 2021-2022 SMA Negeri 9 Mandau mulai menerapkan pembelajaran tatap muka, dilaksanakan secara shift dan diiringi dengan pembelajaran online menggunakan google classroom. Berdasarkan hasil wawancara yang dilakukan dengan Bapak Ade Agus Putra, S.Pd. sebagai guru Sosiologi kelas X dan XII di SMA Negeri 9 Mandau yang menyatakan bahwa pada semester ganjil (Semester I) pembelajaran dilakukan full daring menggunakan google classroom namun pada semester genap ini pembelajaran dilakukan dengan sistem shift yaitu pembelajaran tatap muka dan daring secara bergantian sesuai pembagian kelompok siswa. Dalam pembelajaran tatap muka dan daring ini dibagi sesuai tingkatan kelas, misalnya pada minggu pertama kelas $\mathrm{X}$ yang melakukan pembelajaran tatap muka maka kelas XI dan XII melakukan pembelajaran secara daring menggunakan google classroom. Kemudian, untuk minggu berikutnya jika kelas XI melakukan pembelajaran tatap muka maka kelas X dan XII melakukan pembelajaran secara daring menggunakan google classroom. Sehingga daapt dikatakan bahwa baik pembelajaran secara daring pada semester Juli Desember 2020 maupun kombinasi daring dan luring pada semester Januari - Juni 2021, guru tetap menggunakan platform google classroom sevagai alat bantu dalam proses pembelajaran.

Pelaksanaan pembelajaran era pandemi menggunakan google classroom membutuhkan kesiapan guru dan kesiapan siswa. Dari segi waktu pelaksanaannya pada semester Juli- 
Desember 2020, guru sudah tepat waktu dalam memulai pembelajaran menggunakan hal ini menunjukkan bahwa guru telah mempersiapkan diri untuk mengajar menggunakan platform google classroom, guru juga memiliki kemampuan untuk mengkondisikan siswa, guru juga telah mempersiapkan materi yang akan disampaikan siswa. Akan tetapi sebagian siswa masih terlambat dalam mengikuti pembelajaran hal itu menunjukkan bahwa kesiapan siswa masih kurang, meskipun sebelumnya sudah diingatkan guru di grup whatsapp kelas sebelum memulai pelajaran. Kondisi pelaksanaan pembelajaran pada era pandemi menggunakan google classroom tersebut tidak jauh berbeda dengan pembelajaran pada saat tatap muka dengan sistem shift pada semester Januari-Juni 2021, yang berbeda hanya waktu pelaksaanaan proses belajarnya. Pelaksanaan pembelajaran menggunakan google classroom tersebut meliputi kegiatan pendahuluan, kegiatan inti, dan kegiatan penutup.

Dalam kegiatan pendahuluan ini, guru menanyakan kabar siswa, melakukan absensi, dan menyampaikan tujuan pembelajaran. Pada kegiatan inti guru menyampaikan materi yang akan dipelajari pada pertemuan tersebut, dalam kondisi pembelajaran jarak jauh ini materi disampaiak melalui google classroom dan diskusi dapat dituliskan pada google classroom serta dilanjutkan lebih aktif pada grup whatapps. Setelah materi disampaikan oleh guru, siswa mambaca materi tersebut, mencari sumber literasi lainnya dan menanggapi tersebut melalui penugasan dan forum diskusi. Kemudian pada kegiatan penutup guru menutup pembelajaran menyampaikan simpulan dari materi yang telah dipelajari, menyampaikan materi yang akan disampaikan pada pertemuan selanjutnya dan menutup dengan doa.

Ada beragam hal yang dialami siswa dalam pelaksanaan proses pembelajaran sosiologi menggunakan google classroom pada kelas X IPS di SMA Negeri 9 Mandau. Ada siswa yang paham namun juga ada juga siswa yang merasa kurang berminat, bosan, jenuh belajar mandiri, yang mengakibatkan mereka kurang memahami materi yang dikirimkan pada google classroom dan berdampak pada rendahnya hasil belajar yang diperoleh.

Hasil belajar tidak dapat dipisahkan dari proses belajar, maka hasil belajar tersebut juga dipengaruhi oleh faktor-faktor yang mempengaruhi proses belajar, salah satunya adalah persepsi terhadap pelaksanaan proses pembelajaran. Meskipun banyak stimulus yang berbeda-beda sampai kepada kita tentang masalah yang sama, apa yang dapat kita hayati adalah terbatas pada saat-saat tertentu. Apa yang kita hayati tidak hanya bergantung pada stimulus, tetapi juga pada proses kognitif yang merefleksikan minat, tujuan, dan harapan seseorang pada saat itu pemusatan persepsi disebut "perhatian" (Sobur, 2016).

Persepsi merupakan suatu proses menginterpretasi atau menafsirkan informasi yang diperoleh melalui alat indera manusia. Melalui persepsi manusia terus menerus mengadakan hubungan dengan lingkungannya. Hubungan ini dilakukan melalui inderanya yaitu indera penglihatan, pendengar, peraba, perasa dan pencium (Slameto, 2010). Proses yang didahului oleh penginderaan yakni diterimanya stimulus oleh individu melalui alat indera atau disebut juga proses sensoris. Proses tersebut diteruskan oleh syaraf ke otak sebagai pusat syaraf dan selanjutnya merupakan persepsi (Walgito, 2004). Terjadi proses berpikir yang pada akhirnya terwujud dalam sebuah pemahaman, pemahaman inilah yang kemudian disebut persepsi (Sarwono, 2010). Syarat-syarat terjadinya persepsi adalah adanya objek yang dipersepsi, adanya perhatian, dan adanya alat indera untuk menerima stimulus (Sunaryo, 2004). Sedangkan faktorfaktor yang mempengaruhi persepsi adalah adanya faktor internal yang berasal dari dalam seperti perasaan, sikap dan kepribadian individu, prasangka, keinginan atau harapan, perhatian (fokus), proses belajar, keadaan fisik, gangguan kejiwaan, nilai dan kebutuhan juga minat, dan motivasi. Sedangkan Faktor eksternal atau dari luar terdiri atas intensitas, ukuran, keberlawanan, pengulangan gerakan, hal-hal baru dan familiar, latar belakang keluarga, informasi yang diperoleh, pengetahuan dan kebudayaan sekitar.

Persepsi masing-masing siswa terhadap penggunaan google classroom tidaklah selalu sama. Hal ini dikarenakan karakter, cara berfikir dan latar belakang keluarga dan pengalaman masa

Jurnal Sikola: Jurnal Kajian Pendidikan dan Pembelajaran Vol. 2, No. 4, Th. 2021 
lalu siswa berbeda-beda. Persepsi yang baik terhadap penggunaan google classroom membuat siswa senang dan antusias mengikuti pembelajaran sehingga akan menunjang hasil belajarnya, begitupun sebaliknya. Guru juga mengalami hal yang sama, jika guru memiliki persepsi bahwa penggunaan google classroom menambah beban kerjanya makai a tidak akan maksimal dalam menyampaikan materi secara kreatif kepada siswa.

Dalam proses persepsi perlu adanya perhatian sebagai langkah persiapan dalam persepsi itu. Hal tersebut karena keadaan menunjukkan bahwa individu tidak hanya dikenai oleh satu stimulus saja, tetapi individu dikenai berbagai macam stimulus yang ditimbulkan oleh keadaan sekitarnya. Namun demikian tidak semua stimulus mendapatkan respon individu untuk di persepsi. Stimulus mana yang akan dipersepsi atau mendapatkan respon dari individu tergantung pada perhatian individu yang bersangkutan (Walgito, 2010).

Jika proses pembelajaran menggunakan google classroom menyenangkan maka akan memunculkan persepsi yang baik bagi siswa. Jika siswa memiliki persepsi negatif terhadap penggunaan google classroom dalam pembelajaran daring sosiologi, maka siswa kurang memperhatikan materi yang diajarkan oleh guru dan siswa tidak aktif dalam dalam pembelajaran dan hal tersebut berdampak pada hasil belajarnya (Ahmadi, 2017). Oleh karena itu penting untuk mengetahui persepsi siswa dan guru terhadap penggunaan google classroom dalam pembelajaran, agar dapat diperoleh data analisis kebutuhan yang berguna untuk memperbaiki keberlanjutan proses pembelajaran sosiologi ke depannya. Penelitian ini bertujuan untuk pengetahui persepsi guru dan siswa mengenai pelaksanaan pembelajaran daring menggunakan google classroom. Data penelitian ini dianalisis menggunakan teori konstruktivistik dari Jean Piaget untuk menemukan persepsi yang ada pada diri guru dan siswa terhadap pelaksanaan pembelajaran daring menggunakan google classroom.

\section{Metode Penelitian}

Penelitian ini menggunakan pendekatan kualitatif. Pendekatan ini dipilih untuk mengetahui lebih mendalam tentang persepsi guru serta siswa tentang penggunaan google classroom dalam pembelajaran sosiologi. Maka dengan penelitian kualitatif ini peneliti dapat menjawab pertanyaan tersebut melalui berbagai informasi dan penuturan langsung dari informan yang telah ditentukan sebelumnya. Tipe penelitian ini adalah studi kasus intirinsik (Muri, 2016) karena peneliti ingin mendapatkan pemahaman yang lebih baik tentang salah satu kasus khusus dalam hal ini mengenai persepsi guru serta siswa terhadap penggunaan google classroom dalam pembelajaran daring sosiologi kelas X IPS SMAN 9 Mandau, Duri, Riau. Subjek penelitian adalah guru sosiologi serta siswa kelas X IPS SMA Negeri 9 Mandau, Duri, Riau. Penelitian ini dianalis dengan Teknik pemilihan informan menggunakan purposive sampling yaitu teknik pengambilan data yang tidak didasarkan atas strata, kedudukan, pedoman atau wilayah namun didasarkan oleh adanya tujuan dan pertimbangan yang berhubungan dengan permasalahan penelitian (Sugiyono,2017). Pemilihan informan didasarkan pada kriteria-kriteria tertentu yang dibuat berdasarkan tujuan yang ingin dicapai dan data yang ingin didapatkan. Informan dalam penelitian ini berjumlah 22 orang yang terdiri atas 20 orang siswa dari kelas $\mathrm{X}$ IPS 1- X IPS 4, dan 2 guru mata pelajaran sosiologi di SMA Negeri 9 Mandau, Duri, Riau. Teknik pengumpulan data yaitu melakukan observasi dengan dengan mengamati secara langsung ke lapangan yang akan diteliti (Ritzer, 2014), wawancara dan studi dokumentasi (Sugiyono, 2017). Data dianalisis dengan model Miles dan Huberman yaitu model analisis interaktif dengan langkah mereduksi data, menyajikan data dan penarikan kesimpulan (Basrowi \& Surwandi, 2008). 


\section{Hasil dan Pembahasan}

Berdasarkan hasil penelitian yang sudah dilakukan penggunaan google classroom dalam pembelajaran daring sosiologi menimbulkan berbagai persepsi antara guru dan siswa kelas X IPS SMA Negeri 9 Mandau sebagai berikut:

\section{Persepsi Guru Terhadap Penggunaan Google Classroom dalam Pembelajaran Daring Sosiologi}

Persepsi guru dalam memberikan materi menggunakan google classroom dinilai mudah dan tidak membutuhkan waktu yang lama dalam memberikan materi kepada siswa. Sehingga banyak materi yang bisa diberikan kepada siswa Hal ini diungkapkan dari hasil wawancara dengan Bapak Ade Agus Putra S.Pd. sebagai berikut:

"kalau dilihat dari pemberian materi google classroom ini mudah digunakan karena saya bisa memberikan materinya dalam bentuk yang bervariasi seperti membagikan video pembelajaran, PPT, bahan bacaan seperti bahan ajar, gambar dan link youtube jika diperlukan untuk pendukung materinya. Agar materi sampai kepada siswa, saya hanya perlu mengunggah materi apa yang akan dipelajari siswa pada hari itu, dan siswa bisa langsung melihat materinya. Materinya diberikan secara rinci karena berupa poin-poinnya saja sehingga siswa dapat dengan mudah memehami materinya."

Senada dengan hasil wawancara di atas, Ibu Santun S.Pd. mengungkapkan pengalamannya dalam hal waktu penggunaan yang dibutuhkan untuk mengirimkan materi menggunakan google classroom, sebagai berikut:

"dalam mengirim materi tidak membutuhkan waktu yang lama ya. Karena jika materinya dikirim hari itu maka siswa dapat langsung melihat materinya di laman google classroomnya masing-masing. Materinya juga bisa di jadwalkan sehingga siswa tidak akan terlambat untuk menerima materi. Kita bisa mengirim banyak materi ke google classroom sesuai KD dan tujuan pembelajarannya. Materi-materi yang dibagikan bisa di unduh oleh siswa juga sehingga siswa bisa kapan saja melihat materinya kembali. Google classroom sangat membantu dalam proses belajar mengajar selama pandemi ini."

Dari hasil wawancara di atas dapat disimpulkan bahwa dalam proses belajar mengajar google classroom ini dijadikan media dalam pembelajaran online di masa pandemi dan sangat membantu proses pembelajaran seperti dalam memberikan materi. Google Classroom ini dinilai mudah dan tidak membutuhkan waktu yang lama untuk memberikan materi kepada siswa, guru bisa mengirim banyak materi untuk siswa dalam satu waktu dan bisa dijadwalkan. Guru bisa mengirimkan video pembelajaran dan bahan bacaan untuk siswa yang disesuaikan dengan materi yang akan dipelajari pada hari itu secara rinci dengan menampilkan point-point penting sehingga memudahkan siswa dalam memahami materinya. Guru hanya perlu login ke aplikasi google classroom dan bisa langsung mengirim materi kepada siswa. materi yang disampaikan juga bervariasi bisa berupa video, gambar, PPT, dan bahan bacaan seperti bahan ajar. Guru hanya perlu menggunggah materi ke dalam google classroom tersebut. Kemudian, siswa dapat melihat dan menyimak materi yang dibagikan guru tanpa ada batasan waktu karena materi bisa di buka kapan saja dan materi juga bisa di unduh.

Persepsi guru terhadap penggunaan google classroom dalam memberikan tugas dinilai mudah dan tidak membutuhkan waktu yang lama. Sehingga banyak tugas yang bisa diberikan kepada siswa. Namun, untuk pemberian tugas, guru biasanya hanya memberikan satu tugas untuk satu kali pertemuan. Hal ini diungkapkan dari hasil wawancara dengan Bapak Ade Agus Putra S.Pd., sebagai berikut:

"menurut saya mudah memberikan tugas ke siswa menggunakan google classroom ini, karena saya bisa memilih bentuk tugas yang akan diberikan ke siswa. Guru hanya perlu 
masuk ke aplikasi google classroomnya dan memilih tugas seperti apa yang akan diberikan kepada siswa, bisa berbentuk essay atau soal pilihan ganda, disana banyak pilihannya. Tugas-tugas yang diberikan untuk setiap kali pertemuan, biasanya seperti mengamati video, membuat rangkuman, meringkas dan mengerjakan LKPD yang biasanya siswa saya suruh mengerjakannya kedalam buku latihan saja. Kecuali tugas seperti soal pilihan ganda yang ada di google classroom biasanya langsung dikerjakan di sana".

Berikut hasil wawancara dengan Ibu Santun S.Pd., mengenai penggunaan waktu dalam menggunakan google classroom untuk mengirimkan tugas, sebagai berikut:

"kalau dalam memberikan tugas tidak membutuhkan banyak waktu ya. Karena untuk pengiriman soalnya kita bisa coppast aja soal yang sudah kita buat dan apa yang mau kita tugaskan ke google classroom dan bisa langsung dikirim. Selain itu, kita juga bisa memilih bentuk soalnya seperti apa. Kemudian anak-anak ini di instruksikan untuk mengerjakannya dibuku latihan atau di kertas double folio saja nantinya. Tugasnya juga gak banyak, sesuai materi aja. Ada juga tugas yang dikerjakan langsung di google classroomnya seperti soal-soal pilihan. Kalau ibu ngasih tugasnya ada batas waktu gitu, ada penjadwalannya kapan tugas harus diterima oleh guru tujuannya tu biar anak-anak ni ngerjain tuga dan bisa memahami materi yang sudah dipelajari."

Dari hasil wawancara di atas dapat disimpulkan bahwa dalam memberikan tugas dengan menggunakan google classroom dinilai mudah karena guru bisa memilih tugas seperti apa yang akan diberikan kepada siswa. Misalnya tugas dalam bentuk essay atau pilihan ganda yang bisa dikerjakan langsung oleh siswa di google classroomnya. Namun, biasanya dalam memberikan tugas sosiologi guru membagikan LKPD di google classroom tidak membutuhkan waktu yang lama dalam dalam proses pemberian tugas tersebut karena siswa dapat langsung menerima tugas jika mereka membuka kelas maya di google classroom. Tugas yang diberikan kepada siswa memiliki batas waktu agar mereka dapat mengerjakan tugasnya tepat waktu. Tugas yang setelah selesai pemberian materi untuk satu kali pertemuan dan tidak banya. Bentuk penugasan yang biasa diberi guru adalah mengamati video dan membuat rangkuman, mengerjakan LKPD yang biasanya anak-anak di intruksikan untuk membuatnya ke dalam buku latihan atau kertas folio bergaris.

Persepsi guru mengenai tanggapan siswa terhadap penggunaan google classroom untuk melaksanakan penugasan adalah mudah diakses. Siswa dapat dengan mudah menerima tugas dan mengirimkan tugas yang sudah mereka kerjakan. Sebaliknya, tugas yang dikirim oleh siswa mudah dibuka oleh guru, namun waktu yang dibutuhkan dalam menerima tugas menjadi lebih lama karena banyak siswa yang mengirim tugas terlambat. Hal ini diungkapkan oleh Ibu Santun S.Pd., sebagai berikut:

"menurut saya mudah untuk menerima dan membuka tugas siswa ni. Karena saya menerima tugasnya dalam bentuk foto/gambar biasanya, dan itu sesuai dengan instruksi dari saya juga dan juga mempermudah saya dalam memberi penilaian, karena nantik saat siswa menggunggah tugasnya tampilan yang saya terima di google classroom hampir sama layaknya dengan tampilan FB disitu saya bisa memberikan komentar dan nilai terhadap tugas yang dikirim oleh siswa dan siswa tidak harus ke sekolah untuk mengumpulkan tugasnya."

Berikut hasil wawancara mengenai penggunaan waktu dalam menggunakan google classroom untuk menerima tugas dari siswa, sebagai berikut:

"dalam menerima tugas biasanya membutuhkan waktu yang lama, dan belum maksimal karena banyak siswa yang terlambat mengirim tugasnya. Selain itu banyak siswa yang 
tidak mengumpulkan tugasnya sehingga banyak nilai yang kosong. Kalau ditanya alasannya ada yang malas mengerjakan tugas, ada yang lupa karena menunda membuat tugas, tugas ada juga yang tugasnya dikerjakan pas deadline pengumpulan tugas dan dikirim pas guru mau mengisi buku nilai, ada juga yang beralasan karena jaringanlah, google classroom nya erorlah. Padahal tugas ini udah jauh-jauh hari diberikan. biasanya kalau google classroom error, solusinya siswa bisa mengirim tugasnya melalui WA".

Dari hasil wawancara di atas dapat disimpulkan bahwa dalam menerima dan membuka tugas dari siswa dinilai mudah, hal ini dikarena bentuk tugas yang dikirim siswa berupa foto atau video yang mana mempermudah guru untuk memberikan komentar dan penilaian. Tampilannya google classroom dalam menerima tugas siswa juga tidak jauh beda dengan tampilan media sosial seperti FB. Guru bisa langsung memberikan komentarnya di tugas siswa tersebut sehingga tugas bisa langsung dikoreksi dan dinilai oleh guru dan siswa tidak harus kesekolah untuk mengumpulkan tugasnya. Namun membutuhkan waktu yang lama dalam menerima tugas, karena banyak siswa yang terlambat mengirimkan tugasnya dengan berbagai alasan seperti malas mengerjakan tugas, lupa, tugas yang menumpuk serta menunda mengerjakannya hingga mendekati waktu deadline untuk mengumpulkan tugas. Selain itu banyak siswa yang tidak mengumpulkan tugasnya sehingga banyak nilai yang kosong. Ada juga karena masalah jaringan dan google classroom yang error, sehingga ada siswa yang mengirim tugasnya melalui WA.

Persepsi guru dalam pelaksanaan proses penilaian yang disediakan oleh google classroom adalah variatif, seperti mengadakan ulangan harian dengan cara memberikan soal dalam bentuk pilihan yang disusun secara acak, kemudian siswa menjawab soal tersebut dan setelah selesai mengerjakan ulangan tersebut nilai siswa akan langsung keluar dan siswa dapat melihat berapa nilai yang ia dapat setelah melakukan ulangan harian tersebut. Hal ini diungkapkan oleh Bapak Ade Agus Putra S.Pd., sebagai berikut:

"google classroom bisa digunakan juga dalam melakukan penilaian seperti mengadakan $\mathrm{PH}$, dan menurut saya mudah untuk pengaplikasiannya. Saya melakukan PH nya emang di google classroom karena nilainya juga otomatis keluar. Caranya sama dengan pemberian latihan, yang pertama saya buat soalnya dulu di google form yang mana nanti ada 2 bagian. Bagian pertamanya adalah biodata anak, nanti anak-anak akan mengisi nama kelas dan sesi PH nya, kemudian bagian berikutnya adalah soal-soal UH, waktu yang saya berikan adalah 30 menit. Bentuk soalnya saya buat seperti pilihan ganda tapi saya tidak memberikan huruf ABCDE. Soal dan pilihannya saya buat acak. Gunanya adalah biar anak- anak bisa membaca soalnya lebih teliti dan mandiri dalam mengerjakannya serta tidak bisa meniru jawaban kawannya yang lain."

Dari hasil wawancara di atas dapat disimpulkan bahwa google classroom bisa juga digunakan untuk melakukan penilaian seperti $\mathrm{PH}$. Alasan guru menggunakan google classroom adalah karena dengan penggunaannya yang mudah, guru juga bisa langsung bisa melihat nilai siswa. Guru membuat soal seperti pilihan ganda disusun secara acak dan tidak menampilkan option pilihannya, tujuannya agar siswa tidak bisa mencontoh jawaban temannya. Untuk pelaksanaannya guru memberi waktu 30 menit kepada siswa untuk mengikuti $\mathrm{PH}$ tersebut.

Persepsi guru dalam membelajarkan sikap dan keterampilan melalui pennggunaan google classroom dinilai bisa dilakukan hal ini dilihat dari bagaimana guru menilai sikap siswa selama proses belajar mengajar berlangsung seperti adanya sikap religius, jujur, disiplin dalam mengerjakan dan mengirim tugas serta tanggung jawab terhadap tugas yang diberikan. Hal ini diungkapkan oleh Bapak Ade Agus Saputra, sebagai berikut:

"kalau melihat sikap itu kan sifatnya tersirat, karena kita tidak bertemu langsung dengan siswa, jadi sikap yang kita tanamkan tentu kita harus mengingatkan dan memberi instruksi kepada siswa bahwasanya ketika kita memulai proses pembelajaran tentu kita harus

Jurnal Sikola: Jurnal Kajian Pendidikan dan Pembelajaran Vol. 2, No. 4, Th. 2021 
berdoa terlebih dahulu, guru juga menyampaikan nasehat atau amanat yang diselipkan guru ketika proses pembelajaran berlangsung berupa kata-kata motivasi atau kata-kata apersepsi. Guru juga mengingatkan untuk mengerjakan tugas dengan menanamkan kejujuran dan kemandirian kepada siswa, selain itu bisa dilihat dari bagaimana dia bertanggung jawab atas tugas yang diberikan, apakah ia mengerjakannya atau tidak, selain itu kita juga bisa melihat bagaimana kedisiplinan dia misalnya saat mengisi absen dan mengumpulkan tugas, cara dia bertanya dan merespon pertanyaan dari guru atau temantemannya, bisa dilihat dari segi kesopanannya dan sikap saling menghormati antara sesama."

Dari hasil wawancara diatas dapat disimpulkan bahwa penggunaan Google Classroom dalam membelajarkan sikap dapat dilihat dari bagaimana guru mengola kelas dalam proses belajar mengajar berlangsung. Seperti guru membelajarkan sikap religious, jujur, disiplin dan tanggung jawab.

Persepsi guru dalam membelajarkan keterampilan menggunakan google classroom dinilai juga bisa digunakan dengan cara memberikan tugas yang menghasilkan suatu karya seperti membuat peta konsep, kliping dan video yang bisa mengembangkan kreatifitasnya dan kemampuan desain visual siswa. Hal ini diungkapkan oleh Bapak Ade Agus putra S.Pd., sebagai berikut:

"google classroom dalam membelajarkan keterampilan juga bisa digunakan. Caranya dengan saya berikan tugas seperti pembuatan portofolio, pembuatan peta konsep, dan pembuatan video. Kalau di mata pelajaran sosiologi siswa disuruh membuat video dokumenter singkat bermain peran, video dokumenter, atau video presentasi. Selain siswa mampu memberi argument, mereka juga bisa mengembangkan kreatifitasnya serta kemampuan desain visual dalam mengedit video".

Dari hasil wawancara di atas dapat disimpulkan bahwa google classroom juga dapat digunakan dalam membelajarkan keterampilan siswa dengan cara diberikan penugasanpnugasan yang mana siswa menghasilkan suatu karya seperti membuat peta konsep, kliping dan video yang bisa mengembangkan kreatifitasnya dan kemampuan desain visual siswa.

Persepsi guru terhadap konteks interaksi dengan siswa dapat dilihat dari proses pembalajaran, seperti kegiatan pendahuluan, inti dan penutup. Meskipun interaksi yang terjadi bukan interksi langsung, tapi tetap ada umpan balik dari siswa. Siswa dan guru saling berinteraksi ketika proses pembelajaran pada mata pelajaran sosiologi, pelaksanaan tersebut meliputi kegiatan pendahuluan, kegiatan inti, dan kegiatan penutup. Seperti yang dikatakan oleh Bapak Ade Agus Putra S.Pd., sebagai berikut:

"konteks interaksi guru dan siswa tetap ada meskipun menggunakan google classroom bisa dilihat dari kegiatan belajar mengajar dan sangat membantu dalam proses belajar mengajar. Google classroom ini dijadikan sebagai media dalam melakukan pembelajaran online pada saat pandemi, dalam menggunakan google classroom ini guru bisa memberikan materi, memberikan tugas, dan melakukan penialaian sehingga proses belajar mengajar tetap berlangsung. Pada awal pembelajaran kita melakukan absensi untuk melihat kehadiran siswa. Disitu kita sudah bisa lihat bagaimana respon siswa dengan mengisi daftar hadirnya sesuai dengan jadwal pembelajaran sosiologi. Interaksi guru dengan siswa juga bisa dilihat dari bagaimana dia merespon materi, melakukan tanya jawab/diskusi saat ada materi yang tidak ia pahami. Selain itu adanya feedback dari siswa saat guru memberikan tugas, siswa mengerjakan tugas, dan guru memebrikan nilai juga termasuk adanya interaksi antar guru dan siswa".

Dari hasil wawancara di atas, dapat disimpulkan bahwa penggunaan google classroom dalam konteks interaksi guru dan siswa dilihat dari proses pembalajaran seperti pada kegiatan

Jurnal Sikola: Jurnal Kajian Pendidikan dan Pembelajaran Vol. 2, No. 4, Th. 2021 
pendahuluan, inti dan penutup. Pada awal pembelajaran guru melakukan absensi untuk melihat kehadiran siswa, guru melihat respon siswa dengan mengisi daftar hadirnya sesuai dengan jadwal pembelajaran sosiologi. Interaksi guru dengan siswa juga bisa dilihat dari bagaimana siswa merespon materi, keaktifan siswa melakukan tanya jawab/diskusi saat ada materi yang tidak ia pahami. Selain itu adanya feedback dari siswa saat guru memberikan tugas, siswa mengerjakan tugas, dan guru memberikan nilai juga termasuk adanya interaksi antar guru dan siswa.

\section{Persepsi Siswa kelas X IPS Terhadap Penggunaan Google Classroom dalam Pembelajaran Daring Sosiologi}

Persepsi siswa dalam menerima materi dinilai mudah untuk melihat materi. Materi yang dikirim oleh guru bisa langsung dterima dan mudah dibuka oleh siswa dan tidak membutuhkan waktu yang lama dalam membuka materi dan materi juga bisa diunduh oleh siswa. Hal ini diungkapkan dari hasil wawancara HAA, sebagai berikut:

"mudah buk pakai google classroom ni, saya mudah membuka materi menggunakan google classroom, karena saya tinggal klik video saja buk kalau materinya itu dalam bentuk video, kalau bahan bacaaan seperti bahan ajar saya tinggal download aja buk. Nanti ada notifnya tu, kalau guru udah kirim materinya." (HAA/XIPS2/15-03-2021).

Berikut hasil wawancara yang diungkapkan oleh AS mengenai penggunaan waktu yang dibutuhkan dalam menerima dan membuka materi selama menggunakan Google Classroom, sebagai berikut:

"ndak butuh waktu lama dapat materinya, cepat buk karena materinya udah ada dikasih guru tu buk, materinya didapat sesuai dengan jadwal pelajaran kami buk, materinya tu dikirim dalam bentuk video atau bahan ajar gitu buk. Nantik ada notifnya tu buk, kita masuk aja ke google classroom tinggal kita buka aja materinya buk dan materinya juga bisa kita unduh buk" (AS/XIPS2/15-03-2021).

Berdasrkan dari hasil wawancara di atas dapat disimpulkan bahwa persepsi siswa terhadap penggunaan google classroom dalam menerima materi dinilai mudah untuk digunakan. Materi yang dikirim oleh guru bisa langsung dilihat dan dibuka oleh siswa. Siswa dengan mudah melihat materi yang dikirim oleh guru seperti dalam bentuk video, yang mana siswa bisa langsung menonton video tersebut dan siswa juga bisa mengunduh bahan ajar yang telah dibagikan oleh guru. Persepsi siswa terhadap penggunaan google classroom dalam menerima materi dinilai tidak membutuhkan waktu yang lama untuk membuka menerima materi karena materi yang diterima siswa sudah tersedia di laman google classroomnya. Materi yang dikirim oleh guru bisa langsung dilihat oleh siswa, biasanya materi berupa video dan bahan ajar dan siswa bisa langsung menonton serta mengunduh materi yang telah dibagikan guru.

Persepsi siswa dalam mengerjakan tugas menggunakan google classroom mudah dan tidak membutuhkan banyak waktu untuk mengerjakannya karena siswa bisa langsung memilih jawaban mana yang menurutnya benar. Hal ini diungkapkan dari hasil wawancara AY, sebagai berikut:

"tugas yang dikerjakan langsung di google classroomnya tu kayak latihan yang soalnya pilihan dan mengerjakannya pun mudah buk, tinggal milih jawaban aja. Tapi kalau mengerjakan tugas langsung di google classroom sih jarang, karena kebanyakan tugas yang diberi dikerjakan di buku latihan atau di kertas double folio. Karena gurunya emang nyuruh untuk buat tugasnya di buku latihan tu buk" (AY/XIPS2/15-03-2021).

Berikut hasil wawancara yang diungkapkan oleh MNS mengenai penggunaan waktu yang dibutuhkan dalam mengerjakan tugas menggunakan google classroom, sebagai berikut:

Jurnal Sikola: Jurnal Kajian Pendidikan dan Pembelajaran Vol. 2, No. 4, Th. 2021 
"kami tinggal milih jawabannya aja buk, kalau tinggal pilih kayak gitu gak membutuhkan waktu yang lama buk. Pas baca soal langsung dijawab gitu buk, jadinya ndak lama buk, ada tugas langsung dikerjakan dan bisa langsung dikirim. (MNS/XIPS3/15-03-2021).

Berdasarkan dari hasil wawancara di atas dapat disimpulkan bahwa persepsi siswa terhadap penggunaan google classroom dalam mengerjakan tugas dinilai mudah digunakan, karena tugas yang diberikan berupa soal berbentuk pilihan. Siswa hanya perlu memilih jawaban mana yang menurut mereka benar. Namun, siswa jarang mengerjakan tugas langsung di google classroom tersebut, siswa lebih sering mengerjakan tugasnya dibuku latihan atau di kertas double folio sesuai dengan instruksi dari guru sosiologi. Persepsi siswa terhadap penggunaan google classroom dalam mengerjakan tugas dinilai tidak membutuhkan waktu yang lama karena soal yang dikerjakan oleh siswa biasanya berbentuk soal pilihan ganda. Siswa hanya perlu membaca soal dan memilih jawaban yang benar.

Persepsi siswa dalam mengirimkan tugas menggunakan google classroom mudah dan cepat karena siswa hanya perlu mengirim foto/gambar dari tugas yang telah ia kerjakan, kemudian dikirim/ diunggah di laman pengumpulan tugas. Hal ini diungkapkan oleh ARS, sebagai berikut:

"kalau pakai google classroom ngirim tugasnya mudah buk, biasanya guru tu cuma minta foto tugas yang udah kami buat. Terus dikirim ke google classroomnya kayak mengunggah gambar gitu buk." (ARS/XIPS3/15-03-2021).

Berikut hasil wawancara yang diungkapkan oleh FS mengenai penggunaan waktu yang dibutuhkan dalam mengirimkan tugas selama menggunakan google classroom google classroom, sebagai berikut:

"kalau ngirim gambar tu cepat buk, tinggal foto trus kita kirim foto tu ke google classroomnya. Tapi saya sering terlambat ngirimnya buk karena ada batas waktunya kadang buk, tugas dari guru lain juga banyak buk jadi saya malas buat tugas tu cepat-cepat buk" (FS/XIP2/15-03-2021).

Berdasarkan dari hasil wawancara di atas dapat disimpulkan bahwa persepsi siswa terhadap penggunaan google classroom dinilai mudah dalam mengirimkan tugas. Siswa mengerjakan tugasnya dibuku latihan sosiologi atau di kertas double folio kemudian dikirim dalam bentuk foto/gambar yang diunggah ke laman tugas di google classroom. Selain itu mengirim tugas menggunakan google classroom dinilai dinilai tidak membutuhkan waktu yang lama karena karena siswa hanya perlu mengirim foto/gambar dari tugas yang telah ia kerjakan, kemudian dikirim/ diunggah di laman pengumpulan tugas.

Persepsi siswa dalam mengikuti penilaian/ ujian/ ulangan/ tes menggunakan google classroom bisa digunakan seperti siswa mengikuti ulangan harian menggunakan google classroom yang mana nilainya akan keluar secara langsung dan dapat dilihat oleh siswa. Hal ini diungkapkan oleh RAM, sebagai berikut:

"kalau ulangan di google classroom juga bisa buk. Biasanya berbentuk soal pilihan buk sama dengan latihan bentuk soalnya, sebelum mengerjakan $\mathrm{PH}$ biasanya kami isi biodata dulu buk kayak nama dan kelasnya, trus saya kerjakan UH nya, nilai otomatis langsung keluar sesuai dengan jumlah benar jawaban. Saya juga bisa tau jawaban nomor berapa saja yang salah karena ada tandanya warna merah, tapi masalahnya kadang terkendala sama jaringan, juga waktunya terbatas, misalnya kami disuruh mengerjakannya hanya 30 menit saja, soalnya kadang 20 kadang 25 buk." (RAM/XIPS/15-03-2021). 
Berdasrkan dari hasil wawancara diatas dapat disimpulkan bahwa google classroom juga bisa digunakan untuk mengikuti penilaian. Cara penggunaanya di awali dengan mengisi biodata siswa kemudian siswa bisa membuka halaman berikutnya yang berisi soal dengan jumlah 20-25 soal. Siswa harus mengikuti ulangan dengan batas waktu yang hanya 30 menit.

Persepsi siswa terhadap konteks interaksi dengan guru dapat dilihat dari proses pembalajaran seperti melakukan tanya jawab dan berdiskusi dengan guru. Siswa mengerjakan tugas dan siswa mengirimkan tugasnya, guru yang menerima tugas dari siswa tersebut memeriksa dan memberikan nilai. Seperti yang diungkapkan oleh AC, sebagai berikut:

"disuruh mengisi absen sama guru, lalu saya isi absennya, saya kerjakan tugasnya, kemudian tugasnya saya kirim ke google classroom, guru memeriksa tugas saya dan memberi nilai" (AC/XIPS2/15-03-2021).

Dari hasil wawancara diatas, dapat disimpulkan bahwa penggunaan google classroom dalam konteks interaksi guru dan siswa dilihat dari proses pembelajaran, seperti dalam kegiatan pendahuluan, siswa merespon dan ikut berpartisipasi untuk mengisi absen. Pada kegiatan inti konteks interaksi siswa dan guru dilihat dengan adanya partisipasi siswa dalam melakukan tanya jawab dan berdiskusi dengan guru, kemudian kegiatan penutup dimana siswa diminta untuk mengerjakan tugas dan siswa mengirimkan tugasnya, guru yang menerima tugas siswa tersebut memeriksa dan memberikan nilai. Meskipun interaksi yang terjadi bukan interkasi langsung, tapi tetap ada umpan balik dari guru dan siswa.

\section{Analisis Temuan}

Berdasarkan pemahaman dari asumsi dasar teori konstruktivistik yaitu bahwa belajar sangat mendukung munculnya berbagai pendangan dan interpretasi terhadap realitas, konstruksi pengetahuan, serta aktivitas-aktivitas lain yang didasarkan pada pengalaman. Pandangan konstrukivistik mengemukakan bahwa realitas ada pada pikiran seseorang. Manusia mengkonstruksi dan menginterpretasikannya berdasarkan pengalamannya. Konstruktivistik mengarahkan perhatiannya pada bagaimana seseorang mengkonstruksi pengetahuan dari pengalamannya, struktur mental, dan keyakinan yang digunakan untuk menginterpretasikan objek dan peristiwa-peristiwa. Pandangan konstruktivistik mengakui bahwa pikiran adalah instrumen penting dalam menginterpretasikan kejadian, objek, dan pandangan terhadap dunia nyata, dimana interpretasi tersebut terdiri dari pengetahuan dasar manusia secara individual (Budiningsih, 2005).

Belajar adalah pengalaman, dimana pengalaman itu nantinya dapat mempengaruhi penilaian seseorang terhadap sesuatu yang pernah dialaminya. Seperti pada pembalajaran daring sosiologi menggunakan google classroom, dimana guru dan siswa mempunyai penilaiannya masing-masing terhadap hal ini. Ada siswa yang paham dan senang dan ada juga siswa yang kurang minat dan bosan belajar sosiologi daring dengan menggunakan google classroom.

Penilaian guru serta siswa terhadap senang dan tidaknya terhadap pembelajaran sosiologi dengan menggunakan google classroom ini karena didasarkan pada pengalaman yang pernah dilalui dan dirasakan masing-masing siswa, maka dari itu setiap mereka bisa memberikan pendapat, kesan, dan penilaian yang berbeda-beda terhadap penggunaan google classroom dalam pembelajaran sosiologi. Pada dasarnya pembelajaran menggunakan google classroom di masa pandemi ini merupakan suatu hal yang baik bagi siswa sebab ini dapat melatih mereka berpikir kritis, dan mandiri. Selain itu, pembelajarannya lebih mengutamakan kepada kerja siswa sehingga dalam hal ini siswa dapat meningkatkan keaktifan dan menciptakan kreativitas dalam proses belajaranya.

Teori pembelajaran konstruktivisme berpendapat bahwa orang menghasilkan pengetahuan dan membentuk makna berdasarkan pengalaman mereka (Sugrah, 2020). Sesuai dengan asumsi

Jurnal Sikola: Jurnal Kajian Pendidikan dan Pembelajaran Vol. 2, No. 4, Th. 2021 
dasar dari teori konstruktivistik yaitu bahwa belajar sangat mendukung munculnya berbagai pendangan dan interpretasi terhadap realitas, konstruksi pengetahuan, serta aktivitas-aktivitas lain yang didasarkan pada pengalaman, dimana pengalaman itu nantinya dapat mempengaruhi penilaian seseorang terhadap sesuatu yang pernah dialaminya, sehingga setiap mereka bisa memberikan pendapat, kesan, dan penilaian yang berbeda-beda terhadap penggunaan google classroom dalam pembelajaran sosiologi. Menurut Sumarsih (Sumarsih, 2009) belajar merupakan suatu proses pembentukan pengetahuan. Pembentukan ini harus dilakukan si pebelajar. Ia harus aktif melakukan kegiatan, aktif berfikir, menyusun konsep dan memberi makna tentang halhal yang dipelajari.

Pemberian makna terhadap objek dan pengalaman oleh individu tersebut tidak dilakukan secara sendiri-sendiri oleh guru dan siswa, melainkan melalui interkaksi dalam jaringan sosial yang unik, yang terbentuk baik dalam budaya kelas maupun diluar kelas. Dapat dikatakan bahwa penilaian guru serta siwa dalam penggunaan google classroom dapat menimbulkan persepsi yang didasarkan pada pengalaman, dimana pengalaman itu nantinya dapat mempengaruhi penilaian seseorang terhadap sesuatu yang pernah dialaminya, sehingga setiap mereka bisa memberikan pendapat, kesan, dan penilaian yang berbeda-beda terhadap penggunaan google classroom dalam pembelajaran sosiologi. Persepsi merupakan proses dimana individu-individu mengorganisasikan dan menafsirkan kesan indera mereka agar memberi makna kepada lingkungan mereka (Oktadiana, 2010).

Secara umum google classroom sangat membantu dalam proses belajar mengajar. Google Classroom ini dijadikan sebagai media dalam melakukan pembelajaran online pada saat pandemi, dalam menggunakan google classroom ini guru bisa memberikan materi, memberikan tugas, dan melakukan penialaian sehingga proses belajar mengajar tetap berlangsung.

Persepsi guru dalam penggunaan google classroom dinilai mudah digunakan dalam memberikan materi serta tugas dan tidak membutuhkan waktu yang lama untuk memberikan materi dan tugas tersebut. Sehingga banyak materi dan tugas yang bisa diberikan kepada siswa. Guru tidak dapat sekedar memberikan pengetahuan kepada siswa, melainkan juga siswa membangun sendiri pengetahuannya (Fuad, 2019). Hal yang sama juga dinyatakan oleh Ekawati (Ekawati, 2017) bahwa guru tidak mendominasi pembelajaran, tetapi membantu proses pengkonstruksian pengetahuan siswa berjalan lancar. Guru tidak mentransfer pengetahuan yang dimilikinya, melainkan membantu siswa membentuk pengetahuannya sendiri. Namun, untuk pemberian tugas, guru biasanya hanya memberikan satu tugas untuk satu kali pertemuan, tugas yang diberikan biasanya seperti mengamati video, membuat rangkuman, meringkas dan mengerjakan LKPD. Siswa dilatih melakukan kegiatan generatif seperti membuat pertanyaan, meringkas dan melakukan analogi tentang suatu materi yang telah dibaca atau pelajaran yang telah diikutinya sehingga kegiatan generatif itu berkontribusi pada pembelajaran dan memori siswa (Slavina dalam Ekawati, 2017).

Dalam menerima tugas dari siswa penggunaan google classroom dinilai mudah diterima. Tugas yang dikirim oleh siswa mudah dilihat oleh guru namun dalam menerima tugas membutuhkan waktu yang lebih lama karena banyak siswa yang mengirim tugas terlambat sehingga banyak nilai yang kosong.

Menurut persepsi guru, google classroom dinilai juga bisa digunakan untuk melaksanakan penilaian seperti mengadakan penilaian harian dengan cara memberikan soal dalam bentuk pilihan yang disusun secara acak, kemudian siswa menjawab soal tersebut dan setelah selesai mengerjakan ulangan tersebut nilai siswa akan langsung keluar dan siswa dapat melihat berapa nilai yang ia dapat setelah melakukan penilaian harian tersebut.

Untuk membelajarkan sikap dan keterampilan dengan menggunakan google classroom dinilai bisa dilakukan hal ini dilihat dari bagaimana guru menilai sikap siswa selama proses belajar mengajar berlangsung seperti adanya sikap religius, jujur, disiplin dalam mengerjakan dan mengirim tugas serta tanggung jawab terhadap tugas yang diberikan. Selain itu dalam

Jurnal Sikola: Jurnal Kajian Pendidikan dan Pembelajaran Vol. 2, No. 4, Th. 2021 
membelajarkan keterampilan google classroom dinilai juga bisa digunakan dengan cara memberikan tugas yang menghasilkan suatu karya seperti membuat peta konsep, kliping dan video yang bisa mengembangkan kreatifitasnya dan kemampuan desain visual siswa. Sesuai dengan teori belajar konstruktivistik yang memberikan kebebasan terhadap manusia yang ingin belajar atau mencari kebutuhannya dengan kemampuan menemukan keinginan atau kebutuhan tersebut dengan bantuan fasilitasi orang lain, sehingga teori ini memberikan keaktifan terhadap manusia untuk belajar menemukan sendiri kompetensi, pengetahuan, atau teknologi yang diperlukan guna mengembangkan dirinya sendiri (Rangkuti, 2014).

Kemudian, persepsi siswa dalam menerima materi menggunakan google classroom dinilai mudah untuk menerima dan membuka materi karena membutuhkan waktu yang tidak lama dalam membuka materi dan materi juga bisa diunduh oleh siswa. Materi yang diterima siswa berupa video, gambar, PPT, bahan bacaan atau bahan ajar. Hal yang sama diungkapkan oleh Febrianti (Febrianti, 2021) yang mana dalam melaksanakan pembelajaran daring dengan menggunakan google classroom, guru menggunakan media pembelajaran berupa video pembelajaran, gambar dan juga PowerPoint (PPT). Dengan menggunakan media-media tersebut berupaya untuk menarik siswa untuk tidak bosan dalam melaksanakan pembelajaran daring masa pandemi Covid-19 ini. Melalui google classroom, maka siswa dapat belajar sendiri dari materi yang diunggah oleh guru dalam kelas google classroom yang telah dibuat (Gunawan \& Sunarman, 2017).

Dalam mengerjakan tugas google classroom dinilai mudah dan tidak membutuhkan banyak waktu untuk mengerjakannya karena siswa bisa langsung memilih jawaban mana yang menurutnya benar sama halnya dalam mengirimkan tugas menggunakan google classroom dinilai mudah dan cepat karena siswa hanya perlu mengirim foto/gambar dari tugas yang telah ia kerjakan, kemudian dikirim/ diunggah di laman pengumpulan tugas. Google Classroom dinilai juga bisa digunakan untuk mengikuti penilaianswa mengikuti ulangan harian menggunakan google classroom yang mana nilainya akan keluar secara langsung dan dapat dilihat oleh siswa. Penggunaan aplikasi pembelajaran menggunakan internet membuat siswa juga dapat meningkatkan kemampuan literasinya dengan mencari referensi lain di laman internetnya serta belajar untuk berperilaku disiplin dalam menyelesaikan tugas. (Febrian \& Sylvia, 2019)

Adanya interaksi guru dengan siswa selama penggunaan google classroom dalam pembelajaran daring sosiologi dapat dilihat dari kegiatan dan proses pembelajaran, baik dari kegiatan pembuka, inti dan penutup. Jika dilihat dari kegiatan pembuka, guru melakukan absensi sebelum memulai pembelajaran dengan tujuan untuk memeriksa kehadiran siswa. Kemudian pada kegiatan inti guru memberikan materi dan siswa menerima materi, Siswa mengerjakan tugas dan siswa mengirimkan tugasnya, guru yang menerima tugas dari siswa tersebut memeriksa dan memberikan nilai. Guru juga melakukan penilaian dan melakukan tanya jawab serta berdiskusi antara guru dengan siswa dan siswa dengan siswa. Teori konstruktivis mendukung siswa belajar melalui interaksi dengan orang lain. Siswa bekerja bersama sebagai teman sebaya, menerapkan pengetahuan gabungan mereka untuk solusi masalah. Dialog yang dihasilkan dari upaya gabungan ini memberi siswa kesempatan untuk menguji dan memperbaiki pemahaman mereka dalam proses yang sedang berlangsung (Bada dalam Sugrah, 2020). Walaupun pembelajaran dilakukan seacra daring tetapi interaksi yang terjadi sama halnya dengan pembelajaran yang dilakukan secara luring. Meskipun interaksi yang terjadi bukan interkasi langsung, tapi tetap ada umpan balik dari siswa.

\section{Kesimpulan}

Hasil penelitian menunjukkan bahwa secara umum google classroom sangat membantu dalam proses belajar mengajar. Google Classroom ini dijadikan sebagai media dalam melakukan pembelajaran online pada saat pandemi, dalam menggunakan google classroom ini guru bisa memberikan materi, memberikan tugas, dan melakukan penialaian sehingga proses belajar

Jurnal Sikola: Jurnal Kajian Pendidikan dan Pembelajaran Vol. 2, No. 4, Th. 2021 
mengajar tetap berlangsung. Persepsi guru dalam menggunakan google classroom dinilai mudah digunakan dan tidak membutuhkan waktu yang lama dalam memberi materi, memberi tugas, melakukan penilaian namun dalam menerima tugas dari siswa selama menggunakaan google classroom membutuhkan waktu yang lama karena banyak siswa yang terkambat mengirim tugas. Persepsi siswa dalam menggunakan google classroom dinilai juga mudah dan tidak membutuhkan waktu yang lama dalam menerima materi dari guru, mengerjakan tugas dan mengirimkan tugas serta juga bisa mengikuti penilaian seperti ulangan harian. Google classroom juga bisa digunakan untuk membelajarkan sikap, keterampilan dan bisa digunakan dalam konteks interaksi antara guru dan siswa yang dilihat dari proses pembelajaran selama menggunakan google classroom.

\section{Daftar Pustaka}

Ahmadi, A. (2017). Pengaruh Persepsi Siswa Tentang Guru dan Minat Belajar Terhadap Hasil Belajar Matematika Siswa Kelas X MIA MAN Wajo. Skripsi. UIN Alauddin Makassar.

Ali, M. (2010). Guru dalam Proses Belajar Mengajar. Bandung: Sinar Baru Algesindo.

Annisa, I. K. (2019). Rancangan Pengembangan Instrumen Penilaian Pembelajaran Berbasis Daring. Jurnal Petik, 5(1), 31-47.

Basrowi, B \& Surwandi, S. (2008). Memahami Penelitian Kualitatif. Jakarta: PT. Rineka Cipta.

Budiningsih, A. (2005). Belajar dan Pembelajaran. Jakarta: Rineka Cipta.

Eka, A. W. (2018). Penerapan Google Classroom dalam Pembelajaran Akuntansi. Skripsi. Universitas Islam Indonesia.

Ekawati, M. (2017). Teori Belajar Menurut Aliran Psikologi Kognitif serta Implikasinya dalam Proses Belajar dan Pembelajaran. E-Tech: Jumal Ilmiah Teknologi Pendidikan, 7(2), 1-10

Febrian, R., \& Sylvia, I. (2019). Perilaku Belajar Mahasiswa Pecandu Smartphone di Jurusan $\begin{array}{lllll}\text { Sosiologi FIS UNP. Jurnal Perspektif, } & 2(4),\end{array}$ https://doi.org/10.24036/perspektif.v2i4.110

Febrianti, I. (2021). Implementasi Penggunaan Google Classroom pada Pembelajaran Daring Masa Pandemi Covid-19 di kelas VI Sekolah Dasar. Jambi: Universitas Jambi.

Fuad, Z. Al. (2019). Efektivitas Belajar Daring Siswa SD Banda Aceh-Aceh Besar pada Masa Pandemi Covid 19. Pionir: Jurnal Pendidikan, 9(2), 63-77.

Gunawan, F. I., \& Sunarman, S. G. (2017). Pengembangan Kelas Virtual Dengan Google Classroom Dalam Keterampilan Pemecahan Masalah (Problem Solving) Topik Vektor Pada Siswa Smk Untuk Mendukung Pembelajaran. Prosiding Seminar Nasional Etnomatnesia, 340-348.

Imaduddin, M. (2018). Membuat Kelas Online Berbasis Android dengan Google Classroom. Yogyakarta: Garudhawaca.

Muri, A. Y. (2016). Metode Kuantitatif, Kualitatif \& Penelitian Gabungan. Jakarta: Kencana.

Oktadiana, F. (2010). Persepsi Siswa Pada Mata Pelajaran Ekonomi (Studi Kasus Peminatan Di Sma Negeri 1 Pontianak). Pontianak: Fakultas Ilmu Keguruan dan Pendidikan UNTAN.

Rangkuti, A. N. (2014). Konstruktivisme dan Pembelajaran Matematika. Darul Ilmi, 2(2), 61-76.

Ritzer, G. (2014). Teori Sosiologi Modern (7th ed.; Triwibowo B.S, Ed.). Depok: Prenadamedia Group.

Sari, B. K. (2015). Evaluasi Penyelenggaraan E-Learning Dalam Pembelajaran Di SMA Negeri Aro Semarang. Skripsi. Universitas Negeri Semarang.

Sarwono, S. W. (2010). Pengantar Psikologi Umum. Jakarta: Rajawali Press.

Setiadi, E. M., \& Kolip, U. (2011). Pengantar Sosiologi. Jakarta: Kencana.

Slameto, S. (2010). Belajar dan Faktor-faktor yang Mempengaruhinya. Jakarta: Rineka Cipta

Sobur, A. (2016). Psikologi Umum. Bandung: Pustaka Setia.

Soekanto, S. (2012). Sosisologi Suatu Pengantar. Jakarta: Raja Grafindo Persada 
Sofyana, L., \& Rozaq, A. (2019). Pembelajaran Daring Kombinasi Berbasis Whatsapp Pada Kelas Karyawan Prodi Teknik Informatika Universitas PGRI Madiun. Jurnal Nasional Pendidikan Teknik Informatika: JANAPATI, 8(1), 81-86.

Sugiyono, S. (2017). Metode Penelitian Kualitatif, Kuantitatif, dan $R \& D$. Bandung: Alfabeta.

Sugrah, N. U. (2020). Implementasi teori belajar konstruktivisme dalam pembelajaran sains. Humanika, 19(2), 121-138. https://doi.org/10.21831/hum.v19i2.29274

Sumarsih, S. (2009). Implementasi Teori Pembelajaran Konstruktivistik Dalam Pembelajaran Mata Kuliah Dasar-Dasar Bisnis. Jurnal Pendidikan Akuntansi Indonesia, 8(1), 54-62. https://doi.org/10.21831/jpai.v8i1.945

Sunaryo, S. (2004). Psikologi untuk Pendidikan. Jakarta: EGC.

Syaiful Bahri, D. (2011). Psikologi Belajar. Jakarta: Rineka Cipta.

Uno, H. B., \& Lamatenggo., N. (2016). Tugas Guru dalam Pembelajaran, Aspek yang Mempengaruhi. Jakarta: Bumi Aksara.

Walgito, B. (2004). Pengantar Psikologi Umum. Yogyakarta: Andi Offset. 